\title{
Medications Errors and Health-Related Quality of Life of Nursing Professionals in Intensive Care Units
}

\author{
Josikélem da Silva Sodré Pelliciotti
}

Miako Kimura²

\begin{abstract}
This study identifies the prevalence of medication errors in ICUs reported by nursing professionals, compares the health-related quality of life (HRQOL) and health status changes of those professionals both involved and not involved with medication errors in ICUs. A total of 94 nursing professionals in three ICUs of a private hospital were studied: $39(41.5 \%)$ nurses and $55(58.5 \%)$ nursing technicians. HRQoL was assessed through the Portuguese version of the SF-36 instrument. Eighteen professionals (19.1\%) reported medication errors during the month prior to data collection. The errors were reported in $61.1 \%$ of the cases and the most frequent ones were those in the administration phase (67.8\%). The professionals who reported medication errors displayed worse health conditions than those who did not report errors.
\end{abstract}

Descriptors: Quality of Life; Health Status; Nursing, Team; Medication Errors; Intensive Care Units.

\footnotetext{
${ }^{1}$ RN, M.Sc. in Nursing, Hospital Sírio Libanês, São Paulo, SP, Brazil. E-mail: josikelem@usp.br, josikelem_sodre@hotmail.com.

2 RN, Ph.D. in Nursing, Associate Professor, Escola de Enfermagem, Universidade de São Paulo, SP, Brazil. E-mail: mikimura@usp.br.
}

Corresponding Author: 


\section{Erros de medicação e qualidade de vida relacionada à saúde de profissionais de enfermagem em unidades de terapia intensiva}

Este estudo teve como objetivos identificar a prevalência de erros de medicação em unidades de terapia intensiva (UTI), relatados por profissionais de enfermagem, comparar a qualidade de vida relacionada à saúde (QVRS) e as alterações no estado de saúde dos profissionais envolvidos e não envolvidos com erros de medicação. Foram pesquisados 94 profissionais de três UTIs de um hospital privado, sendo 39 enfermeiros $(41,5 \%)$ e $55(58,5 \%)$ técnicos de enfermagem. A QVRS foi avaliada pela versão em português do instrumento SF-36. Dezoito profissionais $(19,1 \%)$ mencionaram ter cometido erro no mês anterior à pesquisa. Os erros foram notificados em $61,1 \%$ dos casos e os mais frequentes foram aqueles da fase de administração $(67,8 \%)$. Os profissionais que relataram erro de medicação tiveram tendência a pior estado de saúde, quando comparados aos que não relataram erros.

Descritores: Qualidade de Vida; Nível de Saúde; Equipe de Enfermagem; Erros de Medicação; Unidades de Terapia Intensiva.

\section{Errores de medicación y calidad de vida relacionada a la salud de profesionales de enfermería en Unidades de Terapia Intensiva}

Este estudio tuvo como objetivos: identificar la prevalencia de errores de medicación en UTI relatados por profesionales de enfermería; comparar la calidad de vida relacionada a la salud (CVRS) y las alteraciones en el estado de salud de los profesionales envueltos y no envueltos con errores de medicación. Fueron investigados 94 profesionales de tres UTIs de un hospital privado, siendo 39 enfermeros $(41,5 \%)$ y $55(58,5 \%)$ técnicos de enfermería. La CVRS fue evaluada por la versión en portugués del instrumento SF36. Dieciocho profesionales $(19,1 \%)$ mencionaron haber cometido errores en el mes anterior a la investigación. Los errores fueron notificados en $61,1 \%$ de los casos y los más frecuentes fueron los encontrados en la fase de administración (67,8\%). Los profesionales que relataron errores de medicación tuvieron tendencia al peor estado de salud, cuando comparados a los que no relataron errores.

Descriptores: Calidad de Vida; Estado de Salud; Grupo de Enfermería; Errores de Medicación; Unidades de Terapia Intensiva.

\section{Introduction}

Currently, the health services, especially nursing services, are striving to achieve ever-higher levels of service excellence, aiming to provide care that is free of risk and harm to patients. Adverse events have been considered important indicators of quality of health service and care delivery. Although these are undesirable events, they are commonly observed in care practice and those related to medication errors are themselves frequent.

The National Coordinating Council for Medication Error Reporting and Prevention (NCC MERP) defines medication error as "any preventable event that may cause or lead to inappropriate medication use or patient harm while the medication is in the control of the health care professional, patient, or consumer"(1). A potential medication error is defined as "any error that occurs in any phase of the process, but is detected and corrected before medication is administered to the patient"(2).

The occurrence of medication errors varies according to the hospital sector. In general, areas with a large number of severe patients whose cases are clinically complex, such as emergency units and intensive care units, are more likely to experience the occurrence of these events(3). 
Among the sectors that comprise the hospital system, Intensive Care Units (ICU) differ from other units due to the concentration of technological resources and highly specialized professionals directed to the treatment of patients of greater severity and clinical instability and a consequently low tolerance for diagnostic and therapeutic errors ${ }^{(3)}$. These patients are more exposed to errors since they receive twice as much medication as those hospitalized in general care units and also because they are not accompanied by their family members or are unconscious, which increases their susceptibility to adverse events to an even greater degree.

The complexity of the work performed in an ICU, represented by the use of advanced technology and specific procedures, demands that the nursing professionals from these units be more qualified and have more technical-scientific education in addition to good health condition and quality of life.

Some elements in nursing practice such as those related to the professional, patients or infrastructure, can lead to medication errors. In relation to professionals, individual internal factors include: personality, health condition, professional background, amount of experience in the field, number of jobs worked. Factors external to the individual include: work shift, work dynamics, and professional/patient ratio directly affect not only hospital costs but also patient mortality/morbidity(4-7).

The early identification of latent failures in the organization and system contributes to proactive management, aiming to reduce the impact of work accidents and achieve excellence in both productivity and the quality of care delivery. However, it is clear that this intensified search for higher levels of excellence and productivity in modern society has contributed to compromising professionals' health and quality of life ${ }^{(8)}$.

The construct Health-Related Quality of Life (HRQoL) is defined as "various aspects of a person's life that are affected by changes in health condition and that are significant to one's quality of life"(9). The health and quality of life of nursing professionals have been addressed from different perspectives; however, the literature is scarce in relation to studies addressing the relationship between professionals' quality of life, working conditions and health, and the impact of these factors on medication errors in the specific context of intensive care units.

Therefore, this study primarily aims to answer the following question: Is there a relationship between nursing professionals' HRQoL, general health and the occurrence of medication errors in ICUs? The study's objectives were: to identify the prevalence of medication errors in ICUs reported by nursing professionals and compare HRQoL and changes in the health conditions of professionals both involved and not involved with medication errors.

\section{Methods}

This is an observational and cross-sectional study with a quantitative approach carried out in three ICUs of a private hospital in São Paulo, SP, Brazil: two adult and one pediatric ICU. In a cross-sectional study all measures are taken on a single occasion, with no followup to analyze the relations between variables ${ }^{(10)}$. The study's target population was all the nurses and nursing technicians who belonged to the staff of these ICUs in the studied hospital and who met the following inclusion criteria: being professionally active in one of the three ICUs; having the responsibility of administering medication; and signing a free and informed consent form. The facility has an organized system that records adverse events, including medication errors. There were a total of 119 employees in the three units, of which 42 were nurses and 77 were nursing technicians. Of these, ten were excluded because they were either on vacation or sick leave. Hence, 109 employees were initially included.

A pretest was carried out with the participation of two nurses and three nursing auxiliaries from one hospitalization unit in the same facility. The purpose was to verify whether the instruments were sufficiently clear with no biased questions. The following instruments were used in data collection: 1) an instrument addressing sociodemographic information and the work of the professionals (developed by the researchers) recording information related to personal data, family members, professional education, leisure activities and health conditions in addition to three questions about their involvement with medication errors in the four weeks prior to the study; 2) an instrument to record medication errors filled in by the professionals who reported medication errors aiming to obtain data of the event's characteristics and context; 3) The Medical Outcomes Study 36 - item Short Form Health Survey (SF-36), a version translated into and validated for Portuguese(11), which evaluates HRQoL in the last four weeks through eight dimensions: functional capacity, physical aspects, pain, and overall health status (physical health components); vitality, social aspects, emotional aspects and mental health (mental health components); 4) the validated instrument ${ }^{(12)}$, General 
Health Assessment (GHA), which investigates 28 signs and symptoms of change perceived in health status and the presence of 18 disorders.

The study's proposal was introduced to professionals in each of the work shifts according to the most opportune time indicated by the head nurse. Anonymity and the participation's volunteer nature were ensured. All the questionnaires were delivered at the same time enclosed in an unidentified envelop to be self-completed after receiving instructions and returned sealed within a week to a predefined place. The due date was postponed for another week for those who did not return it on time. Among 109 eligible employees, 94 (86.2\%) returned the completed questionnaires and this number was the total number of participants.

The dependent variable or outcome (committing a medication error) was dichotomous: yes or no. The independent variables or predictors were the scores of the SF-36's eight dimensions (varied from 0 to 100 points) and the GHA's total score corresponding to the sum of the scores obtained in the two parts - signs/symptoms and diagnosed disorders (varying from 0 to 120 points) that classifies health condition as: good $=0$ to 43 points; regular $=44$ to 87 points and poor $=88$ to 130 points.

Statistical analysis was performed using the SPSS (Statistical Package for the Social Sciences) for Windows 12.0 and Stata 8.0. Categorical variables (gender, marital status, caregiver condition, work unit, shift, other jobs, health changes, period of occurrence, occurrence report, number of errors, error consequences) were analyzed through absolute ( $n$ ) and relative (\%) frequencies and averages and standard deviation were computed for continuous variables (age, family income, number of courses, leisure activities, years of professional experience and work in the unit, number of patients, sleep hours, sick leave, missed days at work, times one was late for work, SF-36 domains and scores of health changes and disorders, last day off, vacation, and worked hours before the event). Student's t test was used to compare the averages between independent groups and Person's Chi-square to test association(13). The SF36 domains scores and health changes were compared between nurses and nursing technicians, and between professionals who reported medication errors and those who did not. The non-parametric Mann-Whitney test was used for these comparisons between the two professions. A level of significance at $5 \%(p<0.05)$ was considered in all analyses. The SF-36's reliability was tested through the analysis of the domain of internal consistency, using Cronbach's alpha coefficient. Values higher than 0.70 indicated internal consistency ${ }^{(14)}$.

The participants' rights were ensured according to Resolution 196/96 of the National Council of Health(15). The project was approved by the Research Ethics Committees at the University of São Paulo (process no 711/2008/CEP-EEUSP) and the studied hospital (registration CEPesq: HSL2008/11). All professionals included in this study voluntarily consented and signed free and informed consent forms.

\section{Results}

Fifteen out of the 109 professionals who met the inclusion criteria did not return the questionnaires or refused to participate, which resulted in a loss of $13.8 \%$. The lost cases and the $94(86.2 \%)$ participants were compared in relation to gender, profession, ICU type (adult or pediatric) and work shift. There was a significant difference in relation to gender ( $9.6 \%$ of loss among women and $26.9 \%$ among men; $p=0.0128$ ) and professional category (2.5\% among nurses and $20.3 \%$ among nursing technicians; $\mathrm{p}=0.0047$ ).

Table 1 - Descriptive statistics of scores obtained by nurses and technicians of ICUs of a private hospital in São Paulo regarding the SF-36 domains and health changes and disorders. São Paulo, SP, Brazil. 2008

\begin{tabular}{|c|c|c|c|c|c|c|c|}
\hline \multirow{2}{*}{ Domains } & \multicolumn{2}{|c|}{ General } & \multicolumn{2}{|c|}{ Nurses } & \multicolumn{2}{|c|}{ Nursing technician } & \multirow{2}{*}{ P value* } \\
\hline & Average (sd) & Min- Max & Average (sd) & Min- Max & Average (sd) & Min- Max & \\
\hline Functional capacity & $82.1(16.6)$ & $30-100$ & $85.6(14.9)$ & $40-100$ & $79.6(17.3)$ & $30-100$ & 0.08 \\
\hline Physical aspects & $68.9(35.7)$ & $0-100$ & $66.7(38.2)$ & $0-100$ & $70.4(34.1)$ & $0-100$ & 0.80 \\
\hline Pain & $59.1(22.1)$ & $10-100$ & $61.6(20.9)$ & $10-100$ & $57.4(23.0)$ & $10-100$ & 0.24 \\
\hline General health status & $69.8(20.6)$ & $15-100$ & $71.0(21.0)$ & $25-100$ & $69.0(20.4)$ & $15-100$ & 0.71 \\
\hline Vitality & $53.8(21.8)$ & $0-100$ & $51.3(20.5)$ & $20-85$ & $55.6(22.7)$ & $0-100$ & 0.30 \\
\hline Social aspects & $69.3(24.2)$ & $12.5-100$ & $70.5(22.9)$ & $12.5-100$ & $68.4(25.3)$ & $12.5-100$ & 0.76 \\
\hline Emotional aspects & $69.9(37.3)$ & $0-100$ & $70.9(37.6)$ & $0-100$ & $69.1(37.3)$ & $0-100$ & 0.73 \\
\hline Mental health & $65.3(21.1)$ & $8-100$ & $65.1(17.9)$ & $32-92$ & $65.4(23.2)$ & $8-100$ & 0.74 \\
\hline Changes and disorders & $59.1(21.4)$ & $26-118$ & $56.6(17.5)$ & $28-100$ & $60.9(23.8)$ & $26-118$ & 0.50 \\
\hline
\end{tabular}

$\mathrm{sd}=$ standard deviation; Min-Max= Minimum-Maximum; * Mann-Whitney test. 
Of a possible variation from 0 to 100 , the domain functional capacity obtained the higher average score (82.1; sd=16.6). The low scores obtained by all the participants in the domains of vitality (53.8; $\mathrm{sd}=21.8$ ), pain (59.1; sd=22.1), and mental health (65.3; sd=21.1) are noteworthy. These were obtained by nurses and technicians. The score regarding health

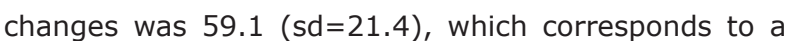
regular general health condition, was obtained by 61 (64.9\%) participants.
The five most prevalent signs and symptoms were related to emotional and gastrointestinal disorders: irritability 32 (34.4\%), headache 30 (31.9\%) and flatulence or abdominal distention 30 (31.9\%), followed by a feeling of indigestion 22 (23.4\%), and depression and unhappiness 20 (21.3\%)

Table 2 records the main disorders presented by professionals and that were diagnosed after being admitted into the ICU.

Table 2 - Comparative characterization of nurses and nursing technicians of ICUs of a private hospital in the city of São Paulo according to health disorders diagnosed by a physician. São Paulo, SP, Brazil. 2008.

\begin{tabular}{|c|c|c|c|c|c|c|c|}
\hline \multirow{2}{*}{ Diagnosed health disorders } & \multicolumn{2}{|c|}{ Nurse } & \multicolumn{2}{|c|}{ Nursing technician } & \multicolumn{2}{|c|}{ Total } & \multirow{2}{*}{$\mathbf{p}$} \\
\hline & $\mathbf{n}$ & $\%$ & $\mathbf{n}$ & $\%$ & $\mathbf{n}$ & $\%$ & \\
\hline Varicose veins & 9 & 23.1 & 15 & 27.3 & 24 & 26 & 0.646 \\
\hline Sinusitis & 4 & 10.3 & 18 & 32.7 & 22 & 23 & 0.011 \\
\hline Gastritis & 8 & 20.5 & 13 & 23.6 & 21 & 22 & 0.720 \\
\hline Herpes, zoster or simple & - & - & 12 & 21.8 & 12 & 13 & 0.002 \\
\hline Hypercholesterolemia & 1 & 2.6 & 6 & 10.9 & 7 & 7.4 & 0.233 \\
\hline Heart arrhythmia & 1 & 2.6 & 5 & 9.1 & 6 & 6.4 & 0.395 \\
\hline Cystitis & 2 & 5.1 & 4 & 7.3 & 6 & 6.4 & 1.000 \\
\hline Hypertension & - & - & 5 & 9.1 & 5 & 5.3 & 0.074 \\
\hline Kidney stone & 2 & 5.1 & 3 & 5.5 & 5 & 5.3 & 1.000 \\
\hline Anemia & 1 & 2.6 & 4 & 7.3 & 5 & 5.3 & 0.399 \\
\hline Colitis & - & - & 4 & 7.3 & 4 & 4.3 & 0.139 \\
\hline Gastric ulcer & - & - & 2 & 3.6 & 2 & 2.1 & 0.509 \\
\hline Eczema & 1 & 2.6 & 1 & 1.8 & 2 & 2.1 & 1.000 \\
\hline Gallstone & 1 & 2.6 & - & - & 1 & 1.1 & 0.415 \\
\hline
\end{tabular}

Eighteen $(19.1 \%)$ out of the 94 professionals to data collection: six nurses and 12 technicians. reported medication errors during the four weeks prior

Table 3 - Distribution of nurses and technicians working in the ICUs of a private hospital of São Paulo involved with medication errors according to variables related to the occurrence of errors. São Paulo, SP, Brazil. 2008

\begin{tabular}{|c|c|c|c|c|c|c|}
\hline \multirow{2}{*}{ Qualitative variables } & \multicolumn{2}{|c|}{$\begin{array}{l}\text { Nurse } \\
(n=6)\end{array}$} & \multicolumn{2}{|c|}{$\begin{array}{l}\text { Nursing technician } \\
(n=12)\end{array}$} & \multicolumn{2}{|c|}{$\begin{array}{c}\text { Total professionals } \\
(n=18)\end{array}$} \\
\hline & $\mathrm{n}$ & $\%$ & $\mathbf{n}$ & $\%$ & $\mathbf{n}$ & $\%$ \\
\hline \multicolumn{7}{|l|}{ Period of occurrence } \\
\hline Day (morning and afternoon) & 3 & $50.0 \%$ & 6 & $50.0 \%$ & 9 & $50.0 \%$ \\
\hline Night (pair and odd nights) & 3 & $50.0 \%$ & 6 & $50.0 \%$ & 9 & $50.0 \%$ \\
\hline Sub Total & 6 & $100.0 \%$ & 12 & $100.0 \%$ & 18 & $100.0 \%$ \\
\hline \multicolumn{7}{|l|}{ Report } \\
\hline Yes & 5 & $83.3 \%$ & 6 & $50.0 \%$ & 11 & $61.1 \%$ \\
\hline No & 1 & $16.6 \%$ & 6 & $50.0 \%$ & 7 & $38.8 \%$ \\
\hline Sub Total & 6 & $100.0 \%$ & 12 & $100.0 \%$ & 18 & $100.0 \%$ \\
\hline \multicolumn{7}{|l|}{ Consequences for the patient } \\
\hline No harm & 6 & $100.0 \%$ & 12 & $100.0 \%$ & 18 & $100.0 \%$ \\
\hline \multicolumn{7}{|l|}{ Extra concerns on the occasion } \\
\hline Yes & 4 & $66.6 \%$ & 7 & $58.3 \%$ & 11 & $61.1 \%$ \\
\hline No & 2 & $33.3 \%$ & 5 & $41.6 \%$ & 7 & $38.8 \%$ \\
\hline Sub Total & 6 & $100.0 \%$ & 12 & $100.0 \%$ & 18 & $100.0 \%$ \\
\hline
\end{tabular}


Table 3 - (continuation)

\begin{tabular}{lccc}
\hline \multicolumn{1}{c}{ Quantitative variables } & Average $(\mathbf{s d})$ & Average (sd) & Total (sd) \\
\hline Days since the last day off & $3.55(3.01)$ & $4.93(2.73)$ & $4.32(2.88)$ \\
Months since the last vacation & $5.95(3.12)$ & $5.26(3.80)$ & $5.60(3.45)$ \\
Hours before the event & $5.00(3.28)$ & $5.67(2.99)$ & $5.34(3.10)$ \\
\hline
\end{tabular}

Table 3 shows that 18 professionals were equally distributed in relation to the report of occurrences in the day and night shifts: nine in each shift; 11 of the 18 professionals $(61.1 \%)$ mentioned they reported their errors; most of them, 11 (61.1\%), reported they had extra concerns at the occasion. Errors occurred about four days before after the last day off, six months since the last vacation and five continuous worked hours for both professionals.

Table 4 - Distribution of 28 types of errors reported by nurses and technicians of ICUs of a private hospital in the city of São Paulo according to the phase of the medication process. São Paulo, SP, Brazil. 2008

\begin{tabular}{llcc}
\hline $\begin{array}{c}\text { Phase of the } \\
\text { process }\end{array}$ & \multicolumn{1}{c}{ Type of errors } & $\mathbf{n}$ & $\%$ \\
\hline Preparation $(\mathrm{n}=9)$ & Prescription & 4 & 14.3 \\
& Transcription & 3 & 10.7 \\
& Preparation & 2 & 7.1 \\
Administration & Dosage & 4 & 14.3 \\
$(\mathrm{n}=19)$ & Time & 4 & 14.3 \\
& Dosage form & 4 & 14.3 \\
& Administration technique & 3 & 10.7 \\
& Omission & 2 & 7.1 \\
& Non-prescribed medication & 2 & 7.1 \\
& Monitoring & - & - \\
& Deteriorated drug & - & - \\
& Total & 28 & 100 \\
\hline
\end{tabular}

In relation to the frequency of errors, nine (32.1\%) occurrences were reported in the phase of preparation and $19(67.9 \%)$ in administration, totaling 28 errors during the four weeks prior to data collection.

Among the 28 reported types of errors, errors during the administration phase were predominant $(19=67.9 \%)$. The most frequent types of errors were related to the prescription, dosage, time and dosage form, each representing $14.3 \% \quad(n=4)$. Transcription errors and those related to administration technique had equal frequencies of $10.7 \%(n=3)$. The least frequent were preparation, omission and administration of nonprescribed medication with two $(7.1 \%)$ reports each. Monitoring errors or administration of deteriorated drugs were not reported.
Table 5 - Comparison of HRQoL scores and health changes and disorders between those professionals who committed errors and those who did not. São Paulo, SP, Brazil. 2008

\begin{tabular}{|c|c|c|c|}
\hline \multirow{3}{*}{ Variable } & \multicolumn{2}{|c|}{ Medication error } & \multirow{3}{*}{$\mathbf{p}^{*}$} \\
\hline & No & Yes & \\
\hline & $\begin{array}{l}\text { Average } \\
\text { (sd) }\end{array}$ & $\begin{array}{l}\text { Average } \\
\text { (sd) }\end{array}$ & \\
\hline Functional capacity & $82.8(16.9)$ & $79.4(15.1)$ & 0.26 \\
\hline Physical aspects & $73.4(33.8)$ & $50.0(38.4)$ & 0.02 \\
\hline Pain & $60.9(21.8)$ & $51.7(22.8)$ & 0.08 \\
\hline General health status & $72.5(19.1)$ & $58.6(23.2)$ & 0.02 \\
\hline Vitality & $56.5(22.2)$ & $42.5(16.2)$ & 0.01 \\
\hline Social aspects & $72.4(23.5)$ & $56.3(23.6)$ & 0.01 \\
\hline Emotional aspects & $75.4(33.3)$ & $46.3(44.5)$ & 0.01 \\
\hline Mental health & $68.2(20.1)$ & $52.9(21.1)$ & 0.01 \\
\hline Health changes and disorders & $56.3(20.3)$ & $71.2(22.2)$ & 0.01 \\
\hline
\end{tabular}

sd=standard deviation; *Mann-Whitney test.

Significant differences were observed between the groups with error and those without errors in relation to the following domains: physical aspects $(p=0.02)$, general health status $(p=0.02)$, vitality $(p=0.01)$, social aspects $(p=0.01)$, emotional aspects $(p=0.01)$ and mental health $(p=0.01)$. A statistically significant $(p=0.01)$ difference in the variable "health changes and disorders" was also found.

\section{Discussion}

The study's 94 participants represented $86.2 \%$ of the 109 professionals who met the inclusion criteria. Among the 94 professionals, 18 (six nurses and 12 technicians) reported medication errors or potential medication errors in the four weeks prior to data collection, representing $19.1 \%$ of the total of participants.

In this study, medication errors most commonly mentioned by the 18 professionals (Table 4 ) occurred in the administration phase followed by errors in the preparation phase $(9=32.1 \%)$.

The administration of medication seems vulnerable to errors due to the absence of monitoring in the process, since most drugs are administered by a single nursing professional. Preparation errors occur when 
there is a difference between the prescription and what was prepared and administered ${ }^{(16)}$. The most frequent medication errors included medicating at the wrong time or with the wrong dosage, which is in agreement with another study(17). Of those professionals involved with errors, $66.7 \%$ reported extras concerns (financial, marital, or family matters) and $61.1 \%$ of these reported they cared for their children at home. Of the 18 professionals involved in occurrences, five (83.3\%) nurses and six $(50.0 \%)$ nursing technicians stated they reported the errors involving medication therapy to the facility's risk management department; an acceptable index of reported cases was found (61.1\%).

The fact that none of the personal or functional aspects studied were associated with medication errors was an unexpected result. We expected, for instance, that a family caregiver would be more associated with medication errors and also that errors would be associated with a larger number of jobs held, as well as with lower incomes. Likewise, we expected a larger number of errors in the pediatric ICU given the characteristics of children that make them more vulnerable to medication errors $^{(18)}$.

The study's participants who committed medication errors reported the event "did not cause any harm" to patients, probably due to the fact that errors did not cause visible harm, that is, they apparently were errors that did not become adverse events. There were no reports of errors in this study that required monitoring, treatment, or caused permanent harm to patients or led to death. There were significant differences in the domains SF-36 and in the general health status of professionals involved with medication errors in ICU and those not involved (Table 5).

The studied nurses and nursing technicians often presented scores worse than those obtained by individuals with diverse pathologies in studies also using the SF-36(19-20). These results are extremely worrying considering that the studied professionals are people fully active in caring for patients in critical condition.

It is also important to note the difficulty in analyzing medication errors since under-reporting is common. Ideally all medication errors and potential medication errors should be reported within 24 hours after the event's occurrence so that the institution becomes aware of the types of errors related to medication and proposes action.

Safety should be encouraged in all institutions to ensure an organizational policy that facilitates identifying and acting on unsafe conditions. Hospital facilities need to allow the discussion of safety issues and have a risk management team to coordinate and plan specific actions to acknowledge risks, treating problems in a multi-professional and systemic manner

The identification of the domains that most negatively affect nursing professionals allow planning actions of health promotion and prevention in order to enable them to make healthy choices in their daily routine, seeking to improve their QoL. Considering the complexity and the multiple factors that underlie the occurrence of medication errors, the aspects identified in this study should be taken into account in a systemic approach in which the health of nursing workers is considered a priority.

Health promotion actions in the different categories of nursing deserve full attention and investment on the part of hospital institutions in an attempt to improve the QoL of professionals and ensure excellence of care to patients.

The results of this study are in agreement with those of other studies ${ }^{(21-23)}$ addressing nursing professionals in other settings in which the maintenance of their health is frequently associated with improved care provided to patients.

\section{Conclusions}

The prevalence of medication errors in ICUs reported by nursing professionals was 28 errors during the four weeks prior to data collection. Eighteen out of the 94 participants were involved with medication errors: six nurses and 12 nursing technicians (19.1\% of the total participants).

In relation to HRQoL and GHA, the domain that presented the highest average score was functional capacity 82.1 ( $s d=16.6$ ) and the domains that displayed the lowest average scores were vitality $53.8(\mathrm{sd}=21.8)$ and pain 59.1 ( $\mathrm{sd}=22.1)$. The GHA presented score of "regular" health.

Despite the fact that no statistically significant differences were found between nurses and technicians in relation to the SF-36 domains, the results show that technicians obtained lower scores in most of the domains, indicating they displayed worse health conditions in relation to nurses. Among the diagnosed heath disorders, the only two disorders that were significant were herpes zoster or simplex, found in 12 nursing technicians and no nurses $(p=0.002)$; sinusitis was reported by 18 technicians and only four nurses $(p=0.011)$.

The association between potential risk factors related to HRQoL, health changes and the condition of having 
committed a medication error displayed the lowest score in all the HRQoL domains and a tendency to worse health condition by the GHA's final score for the group of nursing professionals involved with medication errors.

\section{References}

1. NCCMERP. Definition medication errors [text on the Internet]. Rockville: United States Pharmacopoeia; 2002. [cited 2007 jul. 8]. Available from: http://nccmerp.org/council.html 2. Padilha KG, Secoli SR. Erros na administração de medicamentos. Prat Hosp. 2002;4(19):24-9.

3. Santos $A E$, Padilha KG. Eventos adversos com medicação em serviços de emergência: condutas profissionais e sentimentos vivenciados por enfermeiros. Rev Bras Enferm. 2005;58(4):429-33.

4. Fogarty GJ, McKeon CM. Patient safety during medication administration: the influence of organizational and individual variables on unsafe work practices and medication errors. Ergonomics. 2006;49(5-6):444-56.

5. Tang FI, Sheu SJ, Yu S, Wei IL, Chen $\mathrm{CH}$. Nurses relate the contributing factors involved in medication errors. J Clin Nurs. 2007; 16(3):447-57.

6. McGillis Hall L, Doran D, Pink GH. Nurse staffing models, nursing hours, and patient safety outcomes. J Nurs Adm. 2004;34(1):41-5.

7. Dorrian J, Lamond N, van den Heuvel C, Pincombe J, Dawson D. A pilot study of the safety implications of Australian nurses' sleep and work hours. Chronobiol Int. 2006;23(6):1149-63.

8. Mills PR. The development of a new corporate specific health risk measurement instrument, and its use in investigating the relationship between health and well-being and employee productivity. Environ Health. 2005;28(4):1.

9. Seidl EMF, Zannon CMLC. Qualidade de vida e saúde: aspectos conceituais e metodológicos. Cad Saúde Pública. 2004;20(2):580-8.

10. Hulley SB. Cummings SR, Browner WS, Grady Deborah, Hearst N, Newman TB. Delineando a pesquisa clínica: uma abordagem epidemiológica. 2a ed. Porto Alegre: Artmed; 2003. 11. Ciconelli RM, Ferraz MB, Santos W, Meinão I, Quaresma MR. Tradução para a língua portuguesa e validação do questionário genérico de avaliação de qualidade de vida SF-36 (Brasil SF-36). Rev Bras Reumatol. 1999;39(3):143-50.
12. Chaves EC. Stress e o trabalho do enfermeiro: a influência de características individuais no ajustamento e tolerância ao turno noturno [tese]. São Paulo: Faculdade de Psicologia, Universidade de São Paulo; 1994.

13. Hair Junior JF, Anderson RE, Tatham RL, Black WC. Análise multivariada de dados. 5a ed. Porto Alegre: Bookman; 2005.

14. Nunnaly JC, Bernstein IH. Psychometric theory. New York: McGraw-Hill; c1994.

15. Conselho Nacional em Saúde (BR). Diretrizes e normas regulamentadoras de pesquisa em seres humanos. Resolução 196/96. Brasília (DF): DOU; 1996 p. 21082-5.

16. Moyen E, Camiré E, Stelfox HT. Clinical review: medication errors in critical care. Crit Care. 2008;12(2):208.

17. Barker KN, Flynn EA, Pepper GA, Bates DW, Mikeal RL. Medication Errors observed in 36 health care facilities. Arch Intern Med. 2002;162(16):1897-903.

18. Montgomery VL. Effect of fatigue, workload, and environment on patient safety in the pediatric intensive care unit. Pediatr Crit Care Med. 2007;8(2 Suppl):S11-6.

19. Franceschini J. Avaliação da qualidade de vida em pacientes com câncer de pulmão através da aplicação do questionário Medical Outcomes Study 36-item Short-Form Health Survey. J Bras Pneumol. 2008;34(6):387-93.

20. Martins MRI, Cesarino CB. Quality of life in chronic kidney failure patients receiving hemodialysis treatment. Rev. LatinoAm. Enfermagem. 2005;13(5):670-6.

21. Monteiro CM, Benatti MCC, Rodrigues RCM. Occupational accidents and health-related quality of life: a study in three hospitals. Rev. Latino-Am. Enfermagem. 2009;17(1):101-7.

22. Becker SG, Oliveira MLC. Study on the absenteeism of nursing professionals in a psychiatric center in Manaus, Brazil. Rev. Latino-Am. Enfermagem. 2008;16(1):109-14.

23. Dal Pai D, Lautert L. Work under urgency and emergency and its relation with the health of nursing professionals. Rev. Latino-Am. Enfermagem. 2008;16(3):439-44. 